Jurnal Ners Indonesia, Vol.11 No.1, September 2020

\title{
GAMBARAN TINGKAT PENGETAHUAN PASIEN TENTANG PENCEGAHAN KOMPLIKASI CONGESTIVE HEART FAILURE (CHF)
}

\author{
Amalia Yunita ${ }^{1}$, Sofiana Nurchayati ${ }^{2}$, Sri Utami ${ }^{3}$ \\ 1,2,3 Fakultas Keperawatan Universitas Riau Jalan Pattimura No 9 Gedung G Pekanbaru Riau \\ Kode Pos 28131 Indonesia \\ e-mail:amaliayunita30@gmail.com
}

\begin{abstract}
Abstrak
Congestive Heart Failure (CHF) keadaan jantung mengalami kegagalan dalam memompa darah untuk mencukupi kebutuhan nutrien dan oksigen sel-sel tubuh dan biasanya terjadi pada ventrikel jika tidak ditangani dengan tepat akan menimbulkan komplikasi akibat kurangnya pengetahuan tentang pencegahan. Tujuan penelitian ini adalah untuk mengidentifikasi tingkat pengetahuan pasien dalam melakukan pencegahan terhadap komplikasi CHF. Desain penelitian deskriptif kuantitatif dengan pendekatan crosssectional. Sampel dalam penelitian ini berjumlah 30 responden yang diambil berdasarkan kriteria inklusi menggunakan accidental sampling. Penelitian di lakukan pada tanggal 27-29 Mei 2019 di ruang Poli Jantung dan Krisan RSUD Arifin Achmad Pekanbaru. Alat ukur yang digunakan adalah kuesioner yang telah di uji validitas dan reliabilitas. Analisa yang di gunakan adalah univariat untuk mengetahui distribusi frekuensi. Hasil penelitian diketahui karakteristik responden terbanyak pada umur 46-55 tahun berjumlah 10 orang (33\%), berjenis kelamin laki-laki 20 orang $(70 \%)$, tingkat pendidikan terbanyak SD sebanyak 11 orang (36.7\%). Responden yang memiliki riwayat keluarga dengan CHF sebanyak 17 orang $(56,7 \%)$, dan derajat terbanyak berada pada kelas II berjumlah 18 orang $(60 \%)$. Responden memiliki tingkat pengetahuan kurang baik tentang pencegahan komplikasi CHF sebanyak 14 orang (46,7\%). Disarankan tenaga kesehatan untuk meningkatkan edukasi kepada pasien CHF agar dapat melakukan pencegahan komplikasi CHF dengan baik.
\end{abstract}

Katakunci:Congestive Heart Failure (CHF), Komplikasi, Pencegahan, Pengetahuan

\begin{abstract}
Congestive Heart Failure (CHF) is a condition where the heart experiences a failure to pump blood to meet the nutritional and oxygen needs of the body's cells and usually occurs in the ventricles if not handled properly it will cause complications due to lack of knowledge abaout prevention. Prevention of complications of CHF. Quantitative descriptive study design with a cross-sectional approach. The sample in this study was 30 respondents who are taken based on inclusion criteria using accidental sampling. The research was conducted on 27-29 May 2019 in the cardiac and Krisan hospital Arifin Achmad Pekanbaru. The measuring instrument used was a questionnaire that had beed tested for validity and reliability. Used is univariate to find out the distribution of frequencies. The results of the study that the most number of respondents aged 46-55 years were 10 people (33\%), 20 men (70\%), the highest education level was elementary school as many as 11 people (36.7\%). Respondents who had a family history of CHF were 17 people (56.7\%), and the highest degree was in class II amounting to 18 people (60\%). Respondent had a poor level of knowledge about the prevention of complications of CHF as many a 14 people (46.7\%). It is recomended that they can properly prevent CHF complications.
\end{abstract}

Keywords: Congestive Heart Failure (CHF), Complication, Knowledge, Prevention

PENDAHULUAN

Congestive Heart Failure (CHF) merupakan keadaan jantung mengalami kegagalan dalam memompa darah untuk mencukupi kebutuhan nutrien, oksigen sel-sel tubuh secara adekuat. Biasanya terjadi pada 
Amalia Yunita, Sofiana Nurchayati, dan Sri Utami, Gambaran Tingkat Pengetahuan Pasien tentang Pencegahan Komplikasi Congestive Heart Failure (CHF)

ventrikel kiri, tetapi juga dapat terjadi pada ventrikel kanan (Udjianti, 2010).

Gagal jantung di sebabkan adanya defek pada miokard atau terdapat kerusakan pada otot jantung sehingga suplai darah keseluruh tubuh tidak terpenuhi. Hal lain yang dapat mengakibatkan terjadinya CHF yaitu: kelainan otot jantung, aterosklerosis coroner, hipertensi sistemik atau pulmonal, peradangan dan penyakit miokardium degeneratif (Udjianti, 2010). Tanda dan gejala yang ditimbulkan seperti dipsneu, batuk, malaise, ortopnea, nokturia, kegelisahan dan kecemasan, serta sianosis (Muttaqin, 2009).

Data yang diperoleh melalui World Health menyebutkan bahwa didunia terdapat 20 juta orang pertahun meninggal dunia akibat masalah kardiovaskular. Data dari Riset Kesehatan Dasar (RISKESDAS) Kementerian Kesehatan Indonesia tahun 2018 berdasarkan diagnosis dokter prevalensi penyakit gagal jantung di Indonesia tahun 2018 sebesar 1,5\% atau diperkirakan sekitar 1.017.290 orang (Riskesdas, 2018).

Prevalensi gagal jantung berdasarkan wawancara terdiagnosis dokter pada penduduk Riau sebesar 1,1\% atau sekitar 26.085 orang (RISKESDAS, 2018). Pasien penderita gagal jantung pada tahun 2017 sebanyak 487 orang dan mengalami peningkatan pada tahun 2018 dengan jumlah 673 orang (Rekam Medik RSUD Arifin Achmad Provinsi Riau, 2018).

Pasien gagaljantung sering mengalami rawat inap ulang di rumah sakit akibat adanya kekambuhan. Kekambuhan dapat terjadi akibat pasien tidak memenuhi terapi yang dianjurkan, misalnya melanggar pembatasan diet, melakukan aktifitas fisik yang berlebihan dan tidak dapat mengenali gejala kekambuhan. Hal ini dikarenakan oleh dukungan sosial yang kurang serta ketidaktahuan pasien maupun keluarga (Black \& Hawks, 2009).

Faktor yang dapat menimbulkan perawatan ulang di rumah sakit yaitu gaya hidup yang tidak sehat dan tidak teraturnya pola makan dari pasien, merokok, stress sehingga membuat kondisi pasien akan semakin menurun. Hal tersebut jika tidak segera diatasi dapat menyebabkan komplikasi dan berakibat kepada hospitalisasi ulang (Welly, 2015).

Komplikasi yang dapat terjadi pada CHF seperti: edema paru, infark miokardium akut, syok kardiogenik, emboli limpa, gangguan motorik, perubahan penglihatan (Stilwell, 2011). Pasien CHF harus segera melakukan pencegahan dini terhadap penyakit yang sedang dialami

Langkah yang dapat dilakukan penderita CHF adalah menunda timbulnya serangan berulang yang dapat terjadi kapan saja. Salah satu cara yang dapat dilakukan untuk mencegah terjadinya komplikasi yaitu dengan menerapkan 
Jurnal Ners Indonesia, Vol.11 No.1, September 2020

pola hidup yang baik dan sehat agar dapat mencegah dan menekan angka terjadinya penyakit CHF. Pencegahan yang dapat dilakukan seperti: mengatur jadwal aktivitas atau latihan sehari-hari, melakukan diet rendah garam-rendah, lemak atau diet untuk menurunkan berat badan, program penghentian merokok, dan pengobatan dini terhadap infeksi (Welly, 2013).

CHF tidak hanya merupakan suatu penyakit kardiovaskuler yang terus meningkat namun juga merupakan suatu penyakit yang paling sering memerlukan perawatan ulang dirumah sakit, meskipun pengobatan rawat jalan telah diberikan secara optimal. Hal ini diakibatkan oleh kurangnya pengetahuan (Pangastuti, 2009).

Pengetahuan adalah sesuatu yang diketahui berkaitan dengan proses pembelajaran. Proses belajar ini dipengaruhi berbagai faktor dari dalam, seperti motivasi dan faktor luar berupa sarana informasi yang tersedia, serta keadaan sosial budaya (Riyanto, 2013).

Akintunde (2015) tentang pengetahuan faktor risiko penyakit jantung di kalangan pekerja di Universitas Nigeria bahwa dari 206 responden yang terdiri atas staff akademik dan non akademik,dengan hasil hanya 41 (19,9\%) partisipan yang memiliki pengetahuan baik tentang faktor resiko gagal jantung. Mayoritas $101(49 \%)$ memiliki pengetahuan yang rendah, sementara $64(31,2 \%)$ memiliki pengetahuan menengah tentang faktor resiko gagal jantung.

Dracup (2014) tentang pengetahuan pasien pedesaan mengenai gagal jantung kepada 612 pasien gagal jantung yangtelah terdaftar uji coba pendidikan pedesaan untuk meningkatkan hasil yang dianalisis menggunakan skala pengetahuan gagal jantung. Uji coba dengan regresi linier berganda digunakan untuk mengeksplorasi kontribusi variabel sosio demografi dan uji coba klinis untuk menilai tingkat pengetahuan gagal jantung. Hasil yang didapatkan pada penelitian ini adalah laki-laki dan pasien yang lebih tua mendapat skor secara signifikan lebih rendah dalam pengetahuan gagal jantung dibandingkan para wanita dan pasien yang lebih muda ( $p$ value $=$ 0,002 dan 0,011, masing-masing). Hasil penelitian ini didukung oleh Akintunde dan Dracup menjelaskan bahwa masih kurangnya tingkat pengetahuan masyarakat tentang penyakit CHF.

Studi pendahuluan dilakukan dengan metode wawancara kepada 10 orang responden yang terkena CHF di Poli Jantung RSUD Arifin Achmad pada 18 Desember 2018, mendapatkan hasil dari 10 responden tersebut, 6 dari 10 orang pasien $\mathrm{CHF}$ memiliki tingkat pengetahuan kurang tentang pencegahan komplikasi.

Tujuan penelitian adalah untuk mengidentifikasi tingkat pengetahuan pasien $\mathrm{CHF}$ dalam melakukan pencegahan terhadap komplikasi yang dapat terjadi. 
Amalia Yunita, Sofiana Nurchayati, dan Sri Utami, Gambaran Tingkat Pengetahuan Pasien tentang Pencegahan Komplikasi Congestive Heart Failure (CHF)

\section{METODE PENELITIAN}

Penelitian ini dilaksanakan di Poli Jantung dan Ruangan Krisan RSUD Arifin Achmad yang dimulai dari bulan Januari sampai Mei 2019. Penelitian ini merupakan penelitian deskriptif kuantitatif dengan pendekatan cross sectional dan teknik accidental sampling. Populasi dalam penelitian ini berjumlah 673 pasien CHF yang ada di RSUD Arifin Achmad Provinsi Riau selama tahun 2018 dan sampel pada penelitian ini dengan mengambil jumlah responden minimal sebagai sampel penelitian yaitu berjumlah 30 sampel.

Alat pengumpulan data pada penelitian ini menggunakan kuesioner. Kuesioner digunakan untuk mengukur tingkat pengetahuan responden tentang pencegahan komplikasi. Jumlah pertanyaan terdiri dari 18 pertanyaan dengan menggunakan skala Gutman. Kuesioner yang digunakan telah di lakukan uji validitas dan reliabilitas. Analisa univariat digunakan untuk mendapatkan gambaran karakteristik responden (umur, jenis kelamin, pendidikan, pekerjaan) serta mendapatkan variabel yang diteliti yaitu pengetahuan responden.

\section{HASIL PENELITIAN}

Hasil penelitian yang dilakukan tanggal 27-29 Mei 2019 di Poli Jantung dan ruangan Krisan RSUD Arifin Achmad yaitu:

\section{Karakteristik responden}

Tabel 1

Distribusi frekuensi umur, jenis kelamin, pendidikan terakhir, pekerjaan, status perkawinan, riwayat keluarga, derajat penyakit gagal jantung kongestif.

\begin{tabular}{lccc}
\multicolumn{2}{l}{ Karakteristik Responden } & $\begin{array}{c}\text { Frekuensi } \\
(\mathrm{f})\end{array}$ & $\begin{array}{c}\text { Persentase } \\
(\%)\end{array}$ \\
\hline $\begin{array}{l}\text { Umur } \\
\begin{array}{l}\text { Dewasa } \\
\text { tahun) }\end{array}\end{array}$ & & \\
$\begin{array}{l}\text { Lansia awhir } \\
\text { tahun) }\end{array}$ & $(36-45$ & 4 & 13,0 \\
$\begin{array}{l}\text { Lansia akhir (56-65) } \\
\text { Manula ( } \geq 65 \text { tahun) }\end{array}$ & 10 & 33,0 \\
& 7 & 23,0 \\
& 9 & 30,0 \\
\hline
\end{tabular}

\begin{tabular}{lcc}
$\begin{array}{l}\text { Jenis kelamin } \\
\text { Laki-laki } \\
\text { Perempuan }\end{array}$ & 21 & 70,0 \\
\hline & 9 & 30,0 \\
Pendidikan Terakhir & & \\
SD & 11 & 36,7 \\
SMP/MTS & 7 & 23,3 \\
SMA/SMK & 7 & 23,3 \\
PT & 5 & 16,7 \\
\end{tabular}

$\begin{array}{lcc}\text { Pekerjaan } & 3 & 10,0 \\ \text { PNS } & 5 & 16,7 \\ \text { Swasta } & 3 & 10,0 \\ \text { Buruh } & 19 & 63,3\end{array}$

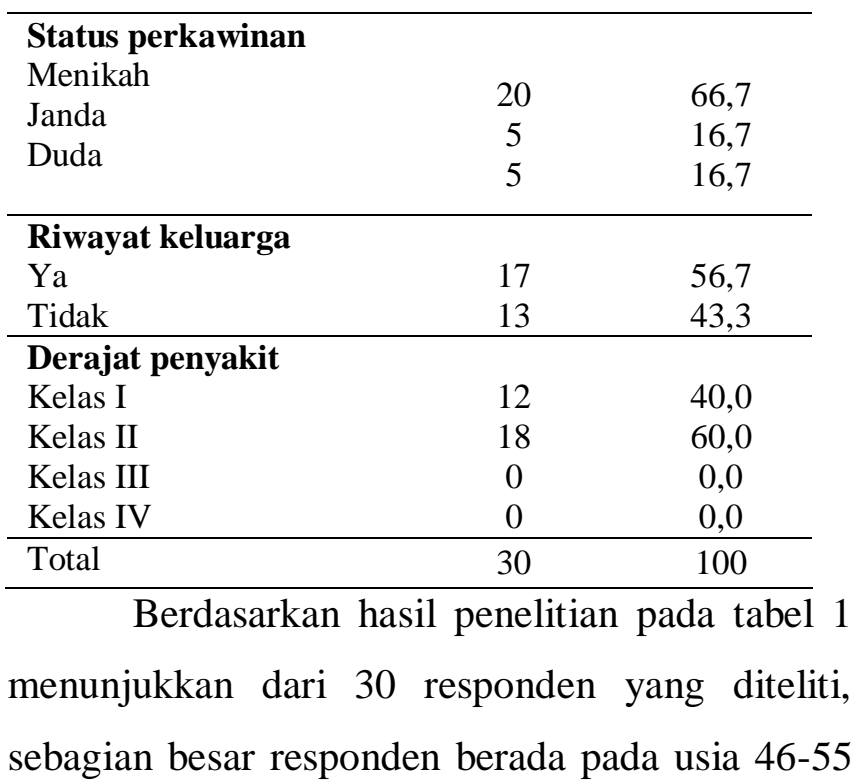


Jurnal Ners Indonesia, Vol.11 No.1, September 2020

tahun sebanyak 10 orang $(33,0 \%)$, mayoritas jenis kelamin responden adalah laki-laki berjumlah 21 orang $(70,0 \%)$, mayoritas pendidikan terakhir responden yakni SD berjumlah 11 orang $(36,7 \%)$, mayoritas pekerjaan yang dimiliki pasien yakni lainlain/IRT sebanyak 19 orang $(63,3 \%)$, sebagian

\begin{tabular}{lcc}
\hline $\begin{array}{c}\text { Tingkat } \\
\text { pengetahuan }\end{array}$ & $\begin{array}{c}\text { Frekuensi } \\
\text { (f) }\end{array}$ & $\begin{array}{c}\text { Persentase } \\
(\%)\end{array}$ \\
\hline Baik & 4 & 13,3 \\
Cukup & 12 & 40,0 \\
Kurang & 14 & 46,7 \\
\hline Total & 30 & 100 \\
\hline
\end{tabular}

besar stastus pernikahan responden yakni menikah sebanyak 20 orang (66,7\%). Sebagian besar pasien tidak mempunyai riwayat keluarga dengan penyakit gagal jantung kongestif yakni 21 orang (70,0\%), dan sebagian besar responden memiliki derajat penyakit jantung pada kelas I sebanyak 21 orang $(70,0 \%)$.

\section{Gambaran tingkat pengetahuan pasien} tentang pencegahan komplikasi $\mathrm{CHF}$

Tabel 2

Distribusi frekuensi responden berdasarkan tingkat pengetahuan tentang pencegahan komplikasi pada pasien $\mathrm{CHF}$

Berdasarkan tabel 2 menunjukkan dari 30 responden yang diteliti, mayoritas memiliki tingkat pengetahuan kurang sebanyak 14 orang $(46,7 \%)$, cukup (40\%), dan baik $(13,3 \%)$.

\section{PEMBAHASAN}

\section{Karakteristik responden}

a. Umur

Hasil penelitian yang telah dilakukan menunjukkan dari 30 orang responden yang di teliti, sebagian responden berada pada usia 46-55 tahun sebanyak 10 orang (33\%). Hasil penelitian ini sesuai dengan penelitian yang dilakukan oleh Nurhayati dan Nuraini (2009), yang meneliti tentang gambaran faktor resiko pada pasien penyakit jantung kongestif berada pada rentang usia lansia awal sebesar $50 \%$.

Distribusi penyakit CHF meningkat pada usia 40 tahun keatas. Hal ini dikarenakan telah terjadinya penurunan fungsi sistem organ tubuh bagian dalam manusia seperti sistem kardiovaskuler. Asumsi dari peneliti tersebut sesuai dengan teori yang menyatakan bahwa dengan meningkatnya usia, jantung dan pembuluh darah mengalami perubahan baik struktural maupun fungsional. Dengan bertambahnya usia, sistem aorta dan arteri menjadi kaku. Perubahan ini akibat hilangnya serat elastis dalam lapisan media arteri (Purbianto, 2015).

\section{b. Jenis kelamin}

Hasil penelitian yang telah dilakukan kepada 30 orang responden menunjukkan hasil bahwa, mayoritas responden berjenis kelamin laki-laki yaitu 21 orang (70\%). Hasil penelitian ini sesuai dengan penelitian yang telah dilakukan Hamzah, Widaryati, Darsih (2016) menyatakan bahwa sebagian besar pasien yang menderita 102 
Amalia Yunita, Sofiana Nurchayati, dan Sri Utami, Gambaran Tingkat Pengetahuan Pasien tentang Pencegahan Komplikasi Congestive Heart Failure $(\mathrm{CHF})$

gagal jantung berjenis kelamin laki-laki (60\%) dan perempuan (40\%).

Joseph, Cedars, Ewald, Geltman, dan Man (2009) menyatakan bahwa insiden gagal jantung kongestif lebih rendah pada perempuan dibanding laki-laki karena pada umumnya laki-laki lebih sering melakukan aktivitas fisik yang dapat memperberat kerja jantung. Selain itu, hormon estrogen dapat melindungi perempuan dari penyakit degeneratif, salah satunya penyakit jantung.

\section{c. Pendidikan}

Hasil penelitian yang telah dilakukan kepada 30 orang responden didapatkan hasil bahwa mayoritas tingkat pendidikan responden adalah SD sebanyak 11 orang (36,7\%). Hasil penelitian ini sesuai dengan penelitian yang dilakukan oleh Harigustin, Dewi, Khoiriyah (2016) menunjukkan bahwa sebagian besar responden berada pada pendidik sekolah dasar (SD) $(37,5 \%)$.

Hal ini sesuai dengan teori yang menyatakan bahwa pendidikan adalah proses pertumbuhan seluruh kemampuan dan perilaku melalui mempertimbangkan umur (proses perkembangan), dan hubungannya dengan proses belajar. Tingkat pendidikan juga merupakan salah satu faktor yang mempengaruhi persepsi seseorang untuk lebih mudah menerima ide-ide dan teknologi yang baru (Notoatmodjo, 2010).

\section{d. Pekerjaan}

Hasil penelitian yang telah dilakukan menunjukkan bahwa dari 30 orang responden mayoritas bekerja sebagai wiraswasta, petani, ibu rumah tangga yaitu 19 orang (63,3\%). Hasil penelitian tersebut sesuai dengan penelitian yang dilakukan oleh Suratinoyo (2016) menyatakan kejadian gagal jantung kongestif paling banyak adalah sebagai wiraswasta berjumlah 11 (33,3\%). Hal ini sesuai dengan teori yang menyatakan pekerjaan yang berat, terus menerus dan kurang beristirahat dapat meningkatkan kerja jantung dalam memompa darah ke seluruh tubuh untuk memenuhi kebutuhan tubuh dalam beraktivitas (Kaplan, 2010).

\section{e. Status pernikahan}

Hasil penelitian yang telah dilakukan menunjukkan bahwa dari 30 orang responden mayoritas status pernikahan responden adalah sudah menikah berjumlah 20 orang $(66,7 \%)$. Hal ini didukung dengan hasil penelitian yang dilakukan Hamzah (2016) yang menemukan penderita gagal jantung kongestif mayoritas berstatus sudah menikah dengan jumlah 45 orang (75\%). Berdasarkan penelitian yang telah dilakukan CHF banyak terjadi pada responden yang telalah menikah dikarenakan faktor stressor ekonomi keluarga yang rendah. Sehingga hal ini memicu kerja jantung yang semakin berat dan akibat stressor yang meningkat. 
Jurnal Ners Indonesia, Vol.11 No.1, September 2020

\section{f. Riwayat keluarga}

Hasil penelitian yang telah dilakukan kepada 30 responden menunjukkan hasil bahwa mayoritas responden memiliki riwayat keluarga yang memiliki gagal jantung kongestif 17 orang $(56,7 \%)$. Hasil penelitian tersebut sesuai dengan penelitian yang dilakukan oleh Purbianto (2015), diketahui sebanyak 42 (43,3\%). Berdasarkan penelitian yang dilakukan kebanyakan responden tidak merubah gaya hidup meskipun telah mengetahui memiliki riwayat keluarga dengan CHF. Faktor kebiasaan pada gaya hidup yang buruk, seperti merokok atau pola makan yang kurang baik yang diwariskan dari satu generasi ke generasi berikutnya dalam suatu kebiasaan hidup disuatu keluarga turut berperan serta dalam peningkatan penyakit kardiovaskuler (Purbianto, 2015).

\section{g. Derajat penyakit}

Hasil penelitian yang dilakukan kepada 30 orang responden didapatkan hasil bahwa mayoritas responden gagal jantung kongestif terbanyak adalah kelas II berjumlah 18 (60\%). Hal ini sesuai dengan penelitian yang dilakukan oleh Malisan, Wantania, dan Rotty (2015) yang menyatakan bahwa pasien gagal jantung kongestif mayoritas berada pada kelas II dengan jumlah 26 (38,8\%) dengan gejala berupa Fatigue, palpitasi, dan dyspnea timbul pada saat aktivitas fisik biasa.

\section{Gambaran tingkat pengetahuan pasien tentang pencegahan komplikasi CHF}

Berdasarkan analisis yang dilakukan oleh peneliti diruangan Krisan dan Poli Jantung RSUD Arifin Achmad kepada 30 orang responden mendapatkan hasil bahwa tingkat pengetahuan yang dimiliki pasien tentang pencegahan komplikasi kurang (46,7\%). Hal ini dikarenakan responden kurang mendapatkan edukasi tentang pencegahan terhadap komplikasi saat melakukan kontrol di rumah sakit. Berdasarkan hasil wawancara yang dilakukan saat pengisian kuesioner dilakukan ada beberapa responden yang mengatakan bahwa hanya datang berobat jika merasakan sakit, selain itu beberapa responden mengatakan saat melakukan kontrol ulang, responden hanya melakukan pemeriksaan tekanan darah dan selanjutnya di berikan obat tambahan. Responden juga mengatakan kurang mencari tahu mengenai penyakit dan apa komplikasi yang dapat terjadi jika tidak segera dilakukan pencegahan. Selain itu, responden tetap mengkonsumsi makanan yang dapat mengakibatkan terjadinya komplikasi. Tidak hanya responden yang sedang melakukan rawat jalan, responden yang sedang berada di ruang rawat inap mengatakan setelah 4 hari di rawat di ruang rawat inap, belum mendapatkan edukasi dari tenaga kesehatan dan hanya mendapat obat serta pemeriksaan EKG. Kurangnya edukasi yang diberikan tenaga kesehatan terhadap responden serta kurangnya tingkat pengetahuan yang dimiliki oleh responden 
Amalia Yunita, Sofiana Nurchayati, dan Sri Utami, Gambaran Tingkat Pengetahuan Pasien tentang Pencegahan Komplikasi Congestive Heart Failure (CHF)

akan berdampak buruk bagi kesehatan pasien dan akan terjadinya komplikasi.

Selain kurangnya edukasi dari tenaga kesehatan, faktor tingkat pendidikan juga mempengaruhi.Hal ini sesuai dengan teori yang ada bahwa, tingkat pendidikan mempengaruhi seseorang dalam menerima informasi baru (Notoatmodjo, 2010). Faktor lain yang mempengaruhi kurangnya pengetahuan yaitu responden kurang mencaritahu sendiri bagaimana cara pencegahan yang dapat dilakukan agar tidak terjadi komplikasi. Kurangnya tingkat pengetahuan pasien tentang pencegahan komplikasi akan berdampak buruk bagi kesehatan pasien dan akan mengakibatkan terjadinya komplikasi.

Hal ini sesuai dengan penelitian yang dilakukan oleh Dracup (2014) tentang pengetahuan pasien pedesaan mengenai gagal jantung kepada 612 pasien gagal jantung yangtelah terdaftaruji coba pendidikan pedesaan untuk meningkatkan hasil yang dianalisis menggunakan skala pengetahuan gagal jantung. Uji coba dengan regresi linier berganda digunakan untuk mengeksplorasi kontribusi variabel sosiodemografi dan uji coba klinis untuk menilai tingkat pengetahuan gagal jantung. Hasil yang didapatkan pada penelitian ini adalah laki-laki dan pasien yang lebih tua mendapat skor secara signifikan lebih rendah dalam pengetahuan gagal jantung dibandingkan para wanita dan pasien yang lebih muda ( $p=0,002$ dan 0,011, masing-masing).

\section{SIMPULAN}

Setelah dilakukan penelitian tentang "gambaran tingkat pengetahuan pasien congestive heart failure tentang pencegahan komplikasi" dapat disimpulkan bahwa sebagian besar umur responden berada pada rentang usia lansia awal sebanyak 33\%, sebagian besar responden berjenis kelamin laki-laki sebanyak 70\%, mayoritas tingkat pendidikan responden berada pada tingkat SD sebanyak $36,7 \%$, sebagian besar pekerjaan responden adalah wiraswasta, petani, ibu rumah tangga sebanyak 63,3\%, dan sebagian besar responden berada pada derajat penyakit kelas II sebanyak $60 \%$.

Hasil penelitian yang dilakukan kepada 30 orang responden yang berada di Poli Jantung dan ruangan Krisan RSUD Arifin Achmad Provinsi Riau bahwa mayoritas pasien memiliki tingkat pengetahuan kurang tentang pencegahan komplikasi sebanyak 46,7\%, baik 13,3\%, cukup $40 \%$.

\section{SARAN}

\section{Bagi perkembangan ilmu keperawatan}

Penelitian ini di harapkan dapat dijadikan sebagai landasan pengembangan khususnya 
Jurnal Ners Indonesia, Vol.11 No.1, September 2020

pada peningkatan pengetahuan pasien tentang pencegahan komplikasi CHF.

\section{Bagi tenaga kesehatan}

Penelitian ini di harapkan dapat dijadikan sebagai bahan dalam memberikan pengetahuan kepada pasien CHF untuk dapat meningkatkan pengetahuan pasien tentang pencegahan komplikasi.

\section{Bagi peneliti selanjutnya}

Penelitian ini diharapkan dapat menjadi sumber informasi dan pengetahuan terkait pencegahan komplikasi CHF pada pasien CHF dan juga dapat mengembangkan hasil penelitian ini dengan lebih dalam lagi terkait pencegahan komplikasi CHF dengan aspek yang berbeda.

\section{DAFTAR PUSTAKA}

Akintunde, A. A. (2015).Knowledge of Heart Disease Risk Factors Among Workers in A Nigerian University: A Call For Concern.Diperoleh tanggal 24 Oktober 2018 dari https://www.ncbi.nlm.nih.gov/pmc/artic les/PMC4382611.

American Heart Association American Heart Association.(2012). Hearth disease and stroke statistic.Diperoleh tanggal pada 13 Januari 2019 dari http://ahajournal.or.com

Arikunto. (2013). Prosedur penelitian suatu pendekatan praktik.Jakarta: Rineka Cipta.

Black, M. J \& Hawks, H. J. (2009).Medical surgical nursing: clinical management for positive outcomes. Ed.8. Singapore.

Dracup. K. (2014). Rural patients' knowledge about heart failure.Diperoleh tanggal
25 Januari $2019 \quad$ dari http://www.ncbi.nlm.nih.gov./pmc/articles/ PMC4380434

Grossman,William\&DonaldS.B. (2009).Grossman'scardiaccatheterization, a ngiography, and intervention,edisi 7.Lippincott Williams\&Wilkins 1-9

Hamzah. R., Widaryati.,\&Darsih. (2016). Hubungan usia dan jenis kelamin dengan kualitas hidup pada penderita gagal jantung di RS PKU Muhammadiyah Yogyakarta.Diperoleh tanggal 30 Mei 2019 dari

http://digilib.unisayogya.ac.id/2256/1/NAS KAH\%20PUBLIKASI\%20\%28RORI\%2OH AMZAH\%29.pdf

Harigustian, Y., Dewi, A., \&Khoiriyati, A. (2016). Gambaran karakteristik pasien gagal jantung usia 45-65 tahun di rumash sakit Pku Muhammadiyah Sleman. Diperoleh pada tanggal 30 Mei 2019 dari http://journal.umy.ac.id/index.php/ijnp/art icle/view/3419.

Joseph, S. M., Cedars, A. M., Ewald, G. a., Geltman, E. M., \& Mann, D. L. (2009).Acute decompensated heart failure: contemporary medical management. Texas heart institute journal childrens's Hospital, $36(6)$, 510-520. https://doi.org/10.1592/phco.23.8.997.328 73

Malisan, E., Wantania, F. E., \& Rotty, L. W. A. (2015). Hubungan kadar hematokrit dengan kelas NYHA pada yang dirawat jalan dan dirawat inap. Jurnal E-Clinic, $3(2)$.

Muttaqin, A. (2009). Asuhan keperawatan klien dengan gangguan sistem kardiovaskular dan hematologi.Jakarta: Salemba Medika.

Notoatmodjo. (2010). Metodologi penelitian kesehatan.Jakarta: Rineka Cipta.

Nurhayati, E., \& Nuraini. (2009). Gambaran faktor resiko pada pasien penyakit gagal jantung kongestif di ruang X.A RSUP Dr. Hasan Sadikin Bandung: Jurnal kesehatan Kartika. Diperoleh tanggal 30 Mei 2019 dari 
Amalia Yunita, Sofiana Nurchayati, dan Sri Utami, Gambaran Tingkat Pengetahuan Pasien tentang Pencegahan Komplikasi Congestive Heart Failure (CHF)

http://stikesayani.ac.id/publikasi/ejour nal/files/2012/201208-008.pdf.

Pangastuti, D. (2009). Asuhan keperawatan dengan gagal jantung kongestif di rumah sakit roemani Semarang.Semarang: $\quad$ Universitas Muhammadiyah Semarang

Purbianto\& Agustanti, D. (2015). Analisis faktor resiko gagal jantung di RSUD Dr. H. Abdul Moeloek Provinsi Lampung.Diperoleh tanggal 30 Mei 2019 dari https://ejurnal.poltekkestjk.ac.id/index.php/JKEP/article/view/5 71

Rekam Medik RSUD Arifin Achmad Pekanbaru. (2018). Rekam medi kpengolahan data. Pekanbaru: RSUD Arifin Achmad Pekanbaru

Riskesdas. (2018). Info pusat data dan informasi kementerian kesehatan RI.Diperoleh tanggal 8 April 2019 dari www.depks.go.id/resource/download/in fo-terkini/hasil-riskesdas-2018.pdf

Riyanto, A. (2014). Kapita selekta kuesioner: pengetahuan dan sikap dalam penelitian kesehatan. Jakarta: Salemba Medika

Stillwell, S. B. (2011).Pedoman keperawatan kritis.Ed.3. Jakarta: EGC.

Suratinoyo, I., Rottie, J. V, \& Massi, G. N. (2016). Hubungan tingkat kecemasan dengan mekanisme kopimg pada pasien gagal jantung kongestif di ruangan CVBC (Cardio Vaskuler Brain Central) Lantai III di RSUP. Prof. DR. R. D. Kadou.Manado.

Udjianti, W. J. (2010). Keperawatan kardiovaskular. Jakarta: Salemba Medika.

Welly. (2013). Faktor - faktor yang berhubungan dengan kejadian penyakit gagal jantung kongestif (CHF; Congestive Heart Failure) di RSUD kota Bekasi. Diperoleh tanggal 09 Januari 2019 dari https://media.neliti.com/.../183438-ID- faktor-faktor-yang-berhubungan-denganke.pdf

WHO. (2014). World health statistic 2012. Vol:27. Diperoleh tanggal 11 November 2018 dari http://doi.org/10.2307/3348165 